\title{
А.Б. Ларин
}

Институт всеобщей истории Российской академии наук, г. Москва, Россия

\section{УКРЕПЛЕНИЕ ПОЗИЦИЙ РОССИИ НА ЮЖНОМ КАСПИИ В 1840-е ГГ. В КОНТЕКСТЕ РУССКО-ИРАНСКИХ ОТНОШЕНИЙ}

\begin{abstract}
Статья посвящена политике России на юге Каспия в 1840-е гг. Показано, что благодаря использованию преимуществ, предоставляемых Туркманчайским трактатом 1828 г., Российской империи удалось значительно укрепить свои позиции в регионе: было расширено военно-морское присутствие, достигнуты существенные успехи в борьбе с пиратством и стабилизации региона, созданы условия для развития торговли. Отдельное внимание уделяется развитию пароходного сообщения на Каспии.

Ключевые слова: Астрабадский залив, о. Ашур-Ада, Каджарский Иран, Каспийское море, Туркманчайский договор, туркмены.
\end{abstract}

A.B. Larin

Institute of World History of the Russian Academy of Sciences, Moscow, Russia

\section{STRENGTHENING OF RUSSIA'S POSITION IN THE SOUTHERN CASPII IN THE 1840S IN THE CONTEXT OF RUSSIAN-IRANIAN RELATIONS}

\begin{abstract}
The article is devoted to the policy of Russia in the south of the Caspian Sea in the 1840s. It is shown that due to the use of the advantages provided by the Turkmanchay Treaty of 1828, the Russian Empire managed to significantly strengthen its position in the region: it expanded its naval presence, achieved significant success in combating piracy and stabilizing the region, and created conditions for the development of trade. Special attention is paid to the establishment of steamship communication in the Caspian Sea.

Key words: Astrabad Gulf, Ashūradeh Island, Qajar Iran, The Caspian Sea, The Treaty of Turkmenchay, Turkmens.
\end{abstract}

В соответствии с Туркманчайским договором 1828 г. Российская империя подтвердила монопольное право держать военный флот на Каспийском море [1, с. 221-222]. Это преимущество создавало возможности (которыми империя не преминула воспользоваться) для обеспечения военно-морского доминирования по всей акватории Каспия, в частности в ее южной части. Этот регион охватывал побережье русского Закавказья на западе, иранских провинций - Гиляна, Мазандарана и Астрабада - на юге и туркменских земель (на которые Каджары также претендовали) - на юго-востоке. Контроль над судоходством позволял обеспечить и большее влияние в регионе в целом.

История освоения Россией прикаспийского региона и самого Каспийского моря не перестает привлекать внимание исследователей, занимающихся разработкой различных аспектов данной темы. Среди работ последних лет можно назвать исследования, посвященные военно-морским силам России в регионе и военно-политической истории российского проникновения [2-5], изучению региона в контексте геополитики и те- ории фронтира [6-8], торгово-экономическим вопросам [9], истории борьбы с пиратством [10]. Эта тема вызывает серьезный исследовательский интерес, что и неудивительно, если принять во внимание существенное геостратегическое и экономическое значение региона, сохраняющееся и в настоящее время.

В качестве источниковой базы послужили материалы различного характера, как опубликованные, так и архивные (Архив внешней политики Российской империи). Обширная проблематика, связанная с Каспием и продвижением России в регионе, нашла отражение в официальных документах, а также в различных материалах личного происхождения: травелогах русских и британцев, личной переписке, материалах прессы и т. д. Большое значение для разработки темы имеют также написанные в XIX в. историко-географические сочинения. Разнородный характер всех этих материалов позволяет рассмотреть избранную проблематику в ее сложности и полноте. Это важно, поскольку избранный для анализа период, с одной стороны, еще не получил всестороннего 
освещения в исследовательской литературе, а с другой - заложил основы последующего доминирования России в южнокаспийском регионе. Исследование тех процессов, что происходили здесь еще в первой половине XIX века, позволит лучше понять дальнейшую сложную историю региона.

В настоящей статье будет уделено внимание различным аспектам политики России на южном Каспии в 1840-е гг., когда ей удается существенно укрепить позиции в регионе. Это было сделано за счет ряда мероприятий, позволивших правительству империи, пользуясь соответствующими статьями Туркманчайского договора, обеспечить себе военно-морскую гегемонию на Каспийском море, что становилось еще одним инструментом влияния на политику Каджарского Ирана. Одновременно осуществлялось и развитие инфраструктуры региона, более тесное его транспортное сопряжение с Россией по морю.

Военно-морская сила России на Каспии была представлена Каспийской флотилией, существовавшей еще с петровских времен. Ввиду обширной площади моря для деятельности флотилии требовалось наличие военно-морских баз («морских станций» в терминологии XIX в.), расположенных по его акватории. Таких станций было создано несколько: на о. Сара, о. Ашур-Ада, в Баку [2]. В совокупности эти ресурсы позволяли решать задачи России в регионе. Если говорить о юго-восточной части Каспия, то непосредственной причиной для усиления здесь российского военно-морского присутствия стала необходимость обеспечения безопасности в связи с нападениями туркмен.

Северо-восточные провинции Ирана, примыкавшие к Астрабадскому заливу, страдали от постоянных набегов туркмен, обитающих к востоку от Каспия. Туркмены нападали на рыболовецкие и торговые суда, курсировавшие в акватории моря, грабили прибрежные промыслы и села. Захваченных в плен иранцев и русских продавали в рабство на рынки Хивы и Бухары $[11$, с. 14, 20]. Эта проблема беспокоила российское общество уже в начале XIX в. [12]. Хотя многие туркмены неоднократно выражали желание вступить в подданство империи, и правительство зачастую оказывало этим туркменским родам посильную поддержку, случаи разбоев и грабежей были явлением не менее обычным [4].

В начале 1840-х гг. правительство принимает серьезные меры для решения проблемы туркменских разбоев. Непосредственным поводом для вмешательства послужили следующие обстоятельства. Персидское правительство неоднократ- но высказывало претензии российским властям в связи с тем, что в силу VIII ст. Туркманчайского договора Иран лишен возможности держать военный флот на Каспии, а значит, остается практически безоружным против туркменских пиратов. Иранские власти даже обвиняли Россию в пособничестве туркменам. В ответ на это правительство с 1841 г. учредило крейсерство у побережья юго-восточной оконечности Каспийского моря.

Туда был направлен военный бриг «Аракс» под командованием капитан-лейтенанта В.И. Фофанова, с тем чтобы он осуществлял надзор за безопасностью в этих водах. Однако даже присутствие российского судна не остановило туркмен от разбоев: продолжались их нападения на иранцев, а осенью 1841 г. туркмены захватили в плен несколько русскоподданных, ограбили лодку русского купца А. Герасимова на виду у военного корабля. Когда же командир предпринял ответные меры, совершили нападение на экипаж судна, убив и ранив несколько человек [13, док. 484]. Эти действия были восприняты как прямое оскорбление достоинства империи, и правительство заняло более решительную позицию.

Каспийская флотилия должна была принять меры для осуществления «строгого полицейского надзора за действиями туркмен, посредством коего прекращены были бы разбои и грабежи, производимые ими в пределах Персии». Руководство миссией по обеспечению безопасности прибрежных вод было поручено капитану 1-го ранга графу Е.В. Путятину, который был командирован в Астрабадский залив в 1842 г. [13, док. 485]. Миссия была успешна: командующему российскими военными судами Путятину удалось не только навести порядок в прибрежных водах, освободить пленных, но и захватить Якши Мухаммеда, лидера туркменских пиратов, и доставить его в Баку [13, док. 488, 491; 14, с. 17-21].

Большое значение для обеспечения военностратегических и экономических интересов России имело создание морской станции на острове Ашур-Ада, занимавшем важную позицию на входе в Астрабадский залив. Ее основание обычно связывают с ликвидацией базы на о. Сара в юго-западной части Каспия и переводом ее на о. Большой Ашур-Ада в 1842-1843 гг. [11, с. 4, 21], хотя М. Кирокосьян отмечает, что станция была учреждена в 1847 г., вне связи с судьбой морской базы на о. Сара [2, с. 75]. Правительство Ирана уступило этот небольшой песчаный остров России для надзора за безопасностью в регионе [11, c. 21]. Ашур-Ада стал постоянным местом базирования российских военных судов на юго-вос- 
точном Каспии вплоть до распада империи. В первое время офицеры и матросы жили на судах. На персидском берегу были построены только баня для моряков и помещение для врача, лечившего иранцев [15, с. 307].

Существование станции на Ашур-Аде вызывало ряд проблем как дипломатического характера, так и связанных непосредственно с назначением станции. Во-первых, персидское правительство относилось к столь близкому присутствию российских военных судов с большой подозрительностью. Иранцы опасались чрезмерного усиления России в регионе, в связи с чем стремились максимально ограничить активность ее представителей. Правительство империи проявляло понимание этой обеспокоенности и старалось не давать иранцам для нее лишних поводов [16, с. 101]. Местные власти, как и местное иранское население, также относились к российской станции с большим недоверием. Значительные сложности представляла и служба на станции. Нездоровый климат местности порождал частые болезни моряков. Туркмены совершали набеги на расположенные на иранском берегу здания [11, с. 21].

Тем не менее станция выполняла свою функцию: современники отмечают, что с появлением станции на Ашур-Аде проблема обеспечения безопасности региона была в целом решена [17, р. 251]. Установленный порядок судоходства в прибрежных водах предполагал получение всеми торговыми судами паспорта у начальника станции, без которого навигация по Каспию была запрещена. Кроме того, моряки станции осуществляли досмотр туркменских кораблей на предмет обнаружения пленников или оружия. Эти меры позволили придать мореплаванию на южном Каспии упорядоченность и обеспечить его безопасность. Разумеется, нападения туркменских пиратов продолжались и в последующие годы, хотя постепенно ситуация стабилизировалась. Российские власти стремились во взаимодействии с туркменами сочетать военную силу с дипломатическими средствами, что, как показало будущее, было наиболее эффективно [2, с. 78-79; 4, с. 33, 36].

Несмотря на все сложности, станция в последующие годы росла и развивалась. С началом пароходства на Каспийском море на станции находились и паровые («Кама», «Волга»), и парусные («Тарантул», «Змея») суда [15, с. 313]. В 1850-е гг. на Ашур-Аде начали строить помещения для офицеров и матросов [15, с. 315].

Кажется очевидным, что целью создания станции на Ашур-Аде была не только борьба с туркменскими разбоями и обеспечение безопасности торговли и русскоподданных. В создании военного укрепления на южном Каспии можно видеть некий ответ на оккупацию острова Харк англичанами в 1838 г. Морская станция на Ашур-Аде стала постоянным элементом российского военного присутствия у каспийского побережья Ирана. Несмотря на относительно скромный масштаб этой базы, она могла в случае необходимости стать важным фактором военно-политического давления на иранские власти. Одновременно, нельзя не отметить и тот факт, что существование станции в известной степени отвечало и интересам самого Ирана Каджаров, так как она защищала в том числе его территорию и подданных, содействовала развитию торговли в регионе [2, с. 78; 4, с. 31-32].

Одной из важнейших задач российского правительства, связанных с дальнейшим освоением акватории моря, было учреждение пароходства на Каспии. О его необходимости писал еще в 1830 г. служивший в Иране дипломат И.С. Мальцов в записке управлявшему Кавказом графу И.Ф. Паскевичу, в которой он рассуждал о мерах, необходимых для развития российской торговли в стране. Мальцов полагал, что одной из причин неразвитости торгового судоходства по Каспию является неизвестность времени доставки товара парусными судами, ввиду чего купцы предпочитают ненадежному морскому сообщению сухопутную доставку, чтобы избежать убытков. Доставка груза пароходами могла бы производиться с меньшими издержками и значительно быстрее, нежели по суше. При этом Россия обладает преимуществом в развитии каспийского судоходства, поскольку на Каспии «развевается один только Русский флаг», и нет необходимости опасаться конкуренции иных держав. Единственным же препятствием к осуществлению учреждения пароходства является несовершенство конструкции паровых судов, что, впрочем, легко может быть преодолено [18, док. 714]. Российское правительство приняло решение по вопросу в 1842 году. Мотивами к осуществлению этого замысла послужили желание обеспечить порядок и безопасность на Каспийском море, в первую очередь - обезопасить море от грабежей туркмен, а также способствовать развитию торговли и установить правильное и скорое сообщение с Персией $[19$, л. 9]. Пароходство позволяло организовать регулярное почтовое сообщение, которое не всегда удавалось осуществлять сухопутным путем. Для реализации этого намерения с позволения императора были заказаны два судна, которые должны были начать плавание осенью 1843 или весной 1844 года $[19$, л. 9]. В то же время правительство столкнулось с определенными трудностями при про- 
ведении в жизнь идеи каспийского пароходства. В частности, необходимым условием регулярного сообщения было обеспечение судов углем, что вызывало затруднения, поскольку доставляемый в Астрахань английский уголь обходился весьма дорого [19, л. 9 - 9 об.].

Для решения этой проблемы правительство стремилось организовать снабжение персидским углем. О наличии в Иране месторождений каменного угля было известно со слов Джафар Кули-бека, иранца, обучавшегося в Горном корпусе. По мнению правительства, снабжение пароходов местным углем позволяло не загружать их топливом на весь рейс (поскольку дозаправку можно было бы произвести на иранском побережье), возможно, этот уголь обходился бы дешевле правительству, нежели английский или российский [19, л. 9 об.].

Чтобы обнаружить месторождения каменного угля, в состав направленной в Персию в начале 1840-х гг. по просьбе иранского правительства миссии горного инженер-майора Н.И. Воскобойникова был включен специалист, опытный в поиске угольных месторождений [19, л. 9 об. - 10]. Любопытно, что правительство предполагало изыскать каменноугольные залежи в прикаспийских провинциях Ирана, не оглашая преждевременно своих намерений относительно их использования [19, л. 10]. Специалист должен был произвести на месте точную разведку месторождений и оценить удобство добычи угля. Желание избежать преждевременной огласки было связано с чрезвычайной подозрительностью первого министра шаха Хаджи-мирзы Агаси, стремившегося скрыть природные богатства Ирана от покушений иностранцев. Таким образом, Воскобойникову было дано весьма деликатное поручение: занимаясь горными изысканиями в местах, указанных иранским правительством, параллельно исследовать Мазандаран и Астрабад на предмет наличия каменного угля $[19$, л. 10]. В случае обнаружения угля подходящего качества Воскобойников должен был выяснить на месте, каких затрат потребует его добыча и доставка его к удобным пунктам на южном берегу Каспия, а также собрать все сведения, которые могли бы оказаться полезными для принятия решений по данному вопросу. Воскобойников должен был сообщить все, что ему удастся обнаружить, посланнику в Иране графу А.И. Медему, а тому, в свою очередь, следовало передать полученную информацию в МИД вместе с собственными заключениями о том, какие условия требуется соблюсти для организации добычи каменного угля в Иране [19, л. 10 - 10 об.]. При этом вице-канцлер граф К.В. Нессельроде выражал надежду, что поскольку основной целью учреждения пароходства на Каспии было прекращение туркменских грабежей, от которых страдали и иранцы, то правительство шаха окажет содействие в снабжении российских паровых судов топливом [19, л. 10 об. - 11]. Но прежде всего предстояло выяснить: «есть ли в Персии каменный уголь, какого он достоинства, в какую цену будет обходиться, на каких условиях может быть приобретаем и с кем надлежит постановить сии условия, т. е. с самим персидским правительством или с частными людьми» $[19$, л. 11].

Предпринятые усилия не пропали втуне. Oceнью 1843 года начальник Главного морского штаба уведомил Нессельроде, что командующий отрядом в Астрабадском заливе капитан-лейтенант Нечаев открыл в окрестностях Астрабада каменный уголь. Персидское правительство, по ходатайству Медема, дало свое согласие на его добычу для российских судов в Астрабадской, Мазандаранской и Гилянской провинциях [19, л. 222]. По этому случаю император повелел отпустить командующему астрабадской морской станцией капитан-лейтенанту Дюгамелю 100 червонцев, чтобы нанять местных жителей для добычи и транспортировки ископаемого топлива. Эти средства должны были поступить из средств российской миссии в Иране. Нессельроде отдельно просил Медема сообщить в МИД о всех подробностях, связанных с открытием угля на южном Каспии. В особенности Нессельроде интересовали обстоятельства исходатайствования Медемом фирмана от персидского правительства, о котором у министерства были лишь косвенные сведения [19, л. 222 - 222 об.].

Впрочем, довольно скоро российские пароходы были вынуждены отказаться от иранского угля. Посетивший в конце 1847 г. Астрабад британский консул Аббот сообщал, что топливо для кораблей доставляется из России, поскольку некоторое время назад снабжение русских астрабадским углем было запрещено персидским правительством [20, р. 36-37]. Переговоры об обеспечении российских судов местным топливом происходили и в 1860-е гг. [21, с. 521].

Российские усилия по организации пароходства на Каспии увенчались успехом несколько позже срока, предполагаемого Нессельроде, - в 1846 г. [22, с. 301]. Активное участие в учреждении почтовых рейсов принимал кавказский наместник князь М.С. Воронцов. Сообщение между портами поддерживалось тремя судами, одно из которых было резервным, на случай задержки очередного парохода. Они развозили почту, пассажиров и товары [23]. Было налажены регулярные рейсы по маршруту: Астрахань - Бирючья Коса - Петров- 
ское укрепление (или Тарки) - Дербент - Баку о. Сара - Энзели - Астрабад со стоянками в некоторых из этих пунктов. Суда отправлялись из Астрахани дважды в месяц, 1 и 15 числа (по юлианскому календарю), дойдя до Астрабада, возвращались обратно по тому же маршруту. Навигация начиналась 1 апреля, и в течение нее суда совершали 13 полных рейсов [24, с. 62]. Подробности этого сообщения, расписание, стоимость проезда и провоза багажа, транспортировки товаров и прочая связанная с каспийским пароходством информация публиковалась в «Кавказском календаре» [25]. Сообщались правила провоза товаров, в частности, указывалось, что при желании отправить морем значительную партию груза торговцу следовало сообщать об этом соответствующим лицам заблаговременно. В этом случае товары грузились на отдельные суда, которые и буксировались пароходами. Товары должны были быть снабжены таможенными свидетельствами на свободный вывоз, а также карантинным свидетельством. Особо оговаривались порядок погрузки товаров и подготовки грузов к отправлению, запрет на транспортировку самовозгорающихся грузов. Важно отметить также и то, что правилами оговаривался порядок отправления пассажиров и грузов из персидских портов в Россию. Всем лицам, желавшим воспользоваться российскими паровыми судами, предписывалось получить виды от миссии или от консульств в Гиляне и Астрабаде. Желавшие перевозить морем коммерческие грузы из Ирана должны были заблаговременно сообщать консулам о количестве и роде товаров, чтобы последние могли отдать распоряжения командующему Астрабадской станцией или командирам пароходов о погрузке товаров на суда [25, с. 200]. Из вышеизложенного можно ясно наблюдать стремление российского правительства упорядочить каспийскую торговлю, создать единые правила морской транспортировки грузов, что позволило бы сделать коммерцию более надежной, спокойной и, в конечном итоге, привлекло бы к ней больше участников. Поскольку же перечисленные пункты остановки российских паровых судов относятся только к западному и южному побережьям Каспийского моря, очевидно, что, организуя регулярное сообщение, правительство рассчитывало на развитие российско-иранских торговых связей. Отсутствие постоянной навигации вдоль восточного побережья объясняется тем, что оно было освоено в значительно меньшей степени и надежные пункты, где могли бы безопасно останавливаться российские корабли, пока отсутствовали.

Вышеописанные мероприятия российского правительства обеспечивали российскую военно-политическую гегемонию на Каспийском море, а также создали возможность для развития торговых связей с Ираном по морю. Вскоре после организации казенного сообщения на Каспии здесь появляются и частные паровые суда: в начале 1850-х гг. в Астрахани было создано частное пароходное общество [26]. Несмотря на то, что персидское правительство первоначально относилось подозрительно к активности России в регионе, с течением времени оно было вынуждено принять ее как данность. В 1866 году Насер-ад-Дин лично посетил Каспийскую флотилию [27]. Во время путешествия в Европу в 1873 г. шах избрал путь по Каспию и далее через Россию [28, р. 17-22]. Отмеченные мероприятия расширение военно-морского присутствия в юговосточной части Каспия, в том числе регулярное крейсирование, создание Астрабадской станции, введение регулярного пароходного сообщения стали важными шагами на пути превращения Каспийского моря в «Русское озеро».

\section{Библиографический список}

1. Юзефович Т. Договоры России с Востоком. Политические и торговые. М., 2005.

2. Кирокосьян М. Российские морские станции на Каспийском море // Морской сборник. 2015. № 10 (2023). С. 71-79.

3. Лобанов В. Б. Каспийская военная флотилия в составе вооруженных сил на юге России (1919-1920 гг.) // Клио. 2012. № 5 (65). С. 91-97.

4. Кадырбаев А. Ш. Россия на Каспийских рубежах: от эпохи Екатерины II до Крымской войны. По материалам Российского государственного архива ВМФ // Восточный архив. 2006. № 14-15. С. 26-37.

5. Кадырбаев А. Ш. Россия на Каспийском море, в Персии и Средней Азии. 1857-1911 гг. По материалам Российского государственного архива ВМФ // Восточный архив. 2015. № 1 (31). С. 4-11.

6. Дарабади П. Влияние «Морской силы» на геополитические процессы на Кавказе: история и современность // Кавказ и глобализация. 2012. Т. 6, вып. 2. С. 53-66.

7. Дарабади П. Кавказско-Каспийский регион в системе геополитических отношений XVIII - начала XIX веков // Кавказ и глобализация. 2008. Т. 2, вып. 4. С. 144-159.

8. Кулаков В. О. Северные провинции Ирана в истории русского фронтира в Прикаспии // Журнал фронтирных исследований. 2016. № 1. С. 57-66. 
9. Корноухова Г. Г. Роль российского правительства в развитии каспийской морской торговли с Персией во второй половине XIX - начале XX в. // Вестник РУДН. Сер. История России. 2019. Т. 18, № 3. С. 661-682.

10. Торопицын И. В. Борьба с пиратством на Каспии в 1730-1740 гг. // Военно-исторический журнал. 2011. № 10. С. 59-63.

11. Соловкин Н. К 70-летию существования Астрабадской морской станции. СПб., 1914.

12. Невольники в Хиве // Вестник Европы. 1815. № 7 (апрель). С. 243-246.

13. Акты, собранные Кавказской археографической комиссией: в 12 т. / ред. А. П. Берже. Тифлис, 1884. Т. 9.

14. Березин И. Путешествие по Дагестану и Закавказью. Казань, 1850.

15. [Мельгунов Г.] О южном береге Каспийского моря. Приложение к III тому записок Императорской Академии наук. № 5. СПб., 1863.

16. Письма Л. Г. Сенявина к посланнику в Тегеране кн. Д. И. Долгорукому // Русский архив. Год 54. Кн. 1. М., 1916. С. 47-128.

17. Holmes W. R. Sketches on the shores of the Caspian, descriptive and pictorial. London, 1845.

18. Акты, собранные Кавказской археографической комиссией: в 12 т. / ред. А. П. Берже. Тифлис, 1878. Т. 7.

19. Архив внешней политики Российской империи. Ф. «Миссия в Персии». Оп. 528 «». 1843-1849 гг. Д. 259.

20. Cities \& Trade: Consul Abbott on the Economy and Society of Iran 1847-1866 / ed. Abbas Amanat. Ithaca Press. London, 1983.

21. Зейдлиц Н. Очерк южно-каспийских портов и торговли // Русский Вестник. 1867. Т. LXX (август).

22. Пароходы // Военный энциклопедический лексикон, издаваемый Обществом военных и литераторов. Ч. 10. СПб., 1846.

23. Каспийское пароходство // Сын Отечества. Обзор истории, политики, словесности, наук и художеств. Кн. V. Май. СПб., 1851. С. 35-36.

24. Пароходные сообщения в России в 1851 году // Современник. СПб., 1851. Т. 28. Отд. VІ. С. 60-62.

25. Расписание пароходных сообщений по портам Каспийского моря на 1852 г. // Кавказский календарь на 1852 год, изданный от канцелярии наместника кавказского. Отд. 2. Тифлис, 1851. С. 193-200.

26. Пароходное Общество в Астрахани // Отечественные Записки. Т. XCII. Отд. VI. СПб., 1854. С. 11.

27. Посещение Каспийской флотилии персидским шахом. Кронштадт, 1866.

28. The diary of H.M. the Shah of Persia during his tour through Europe in A.D. 1873 / trans. J. W. Redhouse. London, 1874. 